\title{
Effect of stunning methods on quality of rabbit carcass and meat
}

*Apata ${ }^{1}$, E.S; ${ }^{1}$ Eniolorunda, O.O; ${ }^{1}$ Amao, K.E; ${ }^{2}$ Okubanjo, A.O.

Meat Science Laboratory; Department of Animal Production, Olabisi Onabanjo University, Yewa Campus, P.M.B 0012 Ayetoro, Ogun State, Nigeria.

Department of Animal Science, Babcock University, Ilishan Remo, Ogun State, Nigeria.

*Correspondent E-mail: ebunoluapata2008@yahoo.com

\begin{abstract}
This study was carried out to evaluate the effect of different stunning methods on the physicochemical and sensory characteristics of rabbit carcass and meat. Thirty six mature rabbits of mixed breeds and sexes with average weight of $1.5-2.0 \mathrm{~kg}$ were used. The rabbits were randomly assigned to four experimental treatments (T1-T4); T1 represented No stunning (control), $T 2=$ Electrical stunning, T3 = Gas stunning and T4 = Mechanical stunning. Each treatment was replicated thrice and the experiment was arranged on completely randomized design. The rabbits were bled after stunning, dressed conventionally and chilled at $4^{0} \mathrm{C}$ for 24 hours. Thereafter the were dissected into 2 halves and fabricated into primal cuts. Carcass characteristics as well as physical, chemical and sensory properties of the rabbit meat were determined. The results showed that carcasses of rabbits stunned with gas gave higher $(P<0.05)$ blood loss and lower $(P<0.05)$ chilling loss. Also visual colour score, cooking yield, protein, nitrogen free extract, cooked meat colour, flavour, texture and overall acceptability were higher $(P<0.05)$, while cooking loss, thermal shortening, drip loss, moisture and $p H$ were lower $(P<0.05)$ in meat from rabbits stunned with gas compared with meat from other treatments. Gas stunning was therefore, recommended since it favoured most of physicochemical and sensory characteristics of both carcass and meat of differently stunned rabbits in this study.
\end{abstract}

Keywords: Evaluation, Meat, Quality, Rabbit, Stunning.

\section{Introduction}

Meat from rabbit is highly digestible, tasty low-calorie and often recommended by nutritionists over other meat types. For this reason, meat processing industries in most part of the world including Europe are gradually expanding and improving the availability of rabbit meat in a large variety of processed ready - meat in order to meet the demands of consumers (Dallezotte, 2002). Meat consumers all over the world are increasingly demanding that food animals be reared, transported and slaughtered with humane practices (Dal bosco et al., 1997). Thus the major concern in the conversion of food animals into edible products is to handle them in a humane and hygienic manner (Mulder, 1999). Therefore, the concern for animal welfare is an important consideration Vis a - vis quality of meat and is consequent upon the belief that animals can suffer and in turn be detrimental to the wholesomeness of the meat from such animals (Manteca, 1998). The procedures that are necessary to convert tissues of a living animal into edible food are stressful and stress before slaughtering animals causes undesirable effects to the quality of meat. Such effects are Pale Soft Exudative (PSE) meat or Dark Firm and Dry (DFD) meat as plasma cortisol, adrenalin and nonadrenalin are affected (Grandin, 1980b; Sams, 1999). However, stunning is one of the important 
slaughtering procedures in the production of meat for food. It is done on animals prior to bleeding in order to immobilize them and render them insensible to pain or stress (Barbut, 2002). There are different methods of stunning animals which include the mechanical or percussion method that entails the use of a captive bolt or hammer, electrical stunning that utilizes a low or high voltage alternating electric current as the case may be and gas stunning method which is the use of carbondioxide $\left(\mathrm{CO}_{2}\right)$ gas. The most essential and preferable attribute of any stunning method is to confer unconsciousness on an animal when stunned without deleterious effect on the animal's carcass or meat (Dalbosco et al., 1997). Grandin (1980a) reported various methods of stunning food animals and their effects on blood and serum, of such animals, with scanty information on the effects of different stunning on the physicochemical and organoleptic quality of carcass and meat. This study was therefore carried out to bridge such gap.

\section{Materials and Methods}

This study was carried out at the Teaching and Research Farm of the College of Agricultural Sciences, Olabisi Onabanjo University, Yewa Campus, Ayetoro, Ogun State, Nigeria.

\section{Animals and their Management}

Thirty six (36) mature rabbits of mixed breeds and sexes with average weight of 1.5 $-2.0 \mathrm{~kg}$ and $6-7$ months old were used for this study. They were purchased and transported to the University's Teaching and Research Farm from rabbit unit of the Ministry of Agriculture, Abeokuta and were kept in previously cleansed, and disinfected house and hutches. The rabbits were acclimatized for two weeks during which they were fed forages (Tridax procumbens), concentrate, clean water ad-libitum with anti-stress and other necessary medication given.

\begin{abstract}
Allocation of Animals into Treatments
The rabbits were randomly assigned to four experimental treatments after two weeks as follows: T1: control (no stunning); T2: Electrical stunning; T3: Gas stunning and T4: Mechanical stunning with each treatment replicated thrice in a completely randomized design.
\end{abstract}

\section{Stunning of Rabbits}

In treatment 1 there was no stunning of rabbits and served as control. Rabbits in treatment 2 were stunned with an electric stunner using current $49 \mathrm{~V}$ for 15 secs (Maria et al., 2000). Rabbits in treatment 3 were stunned with gas (di-ethylether, $400 \mathrm{ml}$ ) poured on a large quantity of cotton wool of $50 \mathrm{~g}$ in a dessicator and each rabbit was introduced into the dessicator for 15 secs, while rabbits in treatment 4 were stunned mechanically using an iron club of $1.2 \mathrm{~kg}$ which was applied on the fore head (Omojola, 2007).

\section{Slaughter of Animals}

The rabbits were bled by severing both the jugular vein and the carotid arteries below the jaws (Okubanjo, 1997). Rabbit carcasses were allowed to bleed for 30 minutes with their heads down (Facco Silveria et al., 1998) and their carcass weights taken after bleeding. Blood quantity was obtained by difference between live and bled carcass weight.

\section{Processing of Rabbit Carcasses}

The rabbits carcasses were skinned as decribed by Omojola and Adesehinwa (2006), opened up, eviscerated, washed and weighed (Okubanjo, 1997). The carcasses were chilled at $4^{\circ} \mathrm{C}$ for 24 hours to reduce carcass temperature and fabricated into primal cuts of leg, loin, rib and shoulder 
according to Aduku and Olukosi (1990).

Measurement of Carcass and Meat Parameters

Carcass physical parameters taken included bled, dressed and chilled weights, dressing percentage, percentage blood and chilling loss as well as bleeding efficiency (Omojola, 2007).

\section{Meat physical Parameters}

Cooking loss and Thermal Shortening

Meat samples of known weight and length were put into an oven and broiled for 25 minutes between $160-180^{\circ} \mathrm{C}$ to an internal temperature of $70^{\circ} \mathrm{C}$. They were removed and cooled to temperature of $25^{\circ} \mathrm{C}$, weighed and their lengths taken. The differences between the initial weight and length and the final weight and length were recorded as the cooking loss and thermal shortening of meat expressed in percentages (Omojola and Adesehinwa, 2006).

Thus;

Cooking loss $=$

Initial meat wt - Final meat wt $\quad \mathrm{x} \quad 100$

Initial meat wt

Thermal shortening $=$

Initial meat length - Final meat length $\quad$ x 100 Initial meat length

\section{Cooking Yield}

This was determined by taking the percentage weight of cooked and raw meat (Okubanjo, 1997). Thus;

Cooking loss $=$

Wt of cooked meat $\times 100$

Wt of raw meat

\section{Drip Loss}

This was determined following the procedures of Insausti et al. (2001). Weight of an empty polythene bag was taken (Wp). Meat sample was put into the bag and weighed $(\mathrm{Wp}+\mathrm{M})$ and then stored in a refrigerator for $48 \mathrm{hrs}$ at $4^{\circ} \mathrm{C}$. The meat sample was removed from the bag and the weight of the bag plus the juice drained by the meat sample were measured $(\mathrm{Wp}+\mathrm{J})$. Drip loss was expressed as percentage of the initial weight of the meat sample thus;

Drip loss $=\underline{(\mathrm{Wp}+\mathrm{J})-(\mathrm{Wp})} \times 100$

$$
(\mathrm{Wp}+\mathrm{m})-(\mathrm{Wp})
$$

\section{Water Holding Capacity (WHC)}

This was carried out according to Suzuki et al. (1991). An approximately $1 \mathrm{~g}$ of meat sample was placed between two $9 \mathrm{~cm}$ Whatman No 1 title papers (Model C, Caver Inc. Wabash, U.S.A). The sandwish was pressed between two $10.2 \times 10.2 \mathrm{~cm}^{2}$ plexiglasses at about $35.3 \mathrm{~kg} / \mathrm{cm}^{3}$ absolute pressure for 1 minute using a vice. The meat samples were removed and oven dried at $105^{\circ} \mathrm{C}$ for 24 hours to determine the moisture content. The amount of water released from the meat samples was measured indirectly by measuring the area of paper relative to the area of pressed meat samples.

$$
\begin{aligned}
& \text { Thus; WHC }= \\
& \frac{100-(\mathrm{Aw}-\mathrm{Am}) \times 9.47}{\text { Wm } \times \mathrm{Mc}} \times 100
\end{aligned}
$$

Where; Aw = Area of water released by meat samples $\left(\mathrm{cm}^{2}\right)$

$$
\text { Am }=\text { Area of meat samples }\left(\mathrm{cm}^{2}\right)
$$$$
\mathrm{Wm}=\text { Weight of meat samples }(\mathrm{g})
$$$$
\mathrm{Mc}=\text { Moisture content of meat }
$$

samples $(\%)$

$$
9.47=\mathrm{a} \text { constant factor }
$$

\section{Raw Meat Visual Colour}

This was determined following the procedures of AMSA (1991). A 10 - man panel was used to score the colour of meat from rabbits stunned with the three methods of stunning, tested on scale $1-10$ where $1=$ low redness and $10=$ high redness.

\section{Shear Force}


Meat objective tenderness (shear force) was determined using a Warner Bratzler v-notch shearing instrument (Honikel, 1998). The meat sample was cored using a cork borer $(1.25 \mathrm{~cm})$ and was sheared at three locations along the fibre direction and the average values of the shearings taken.

Proximate Composition and $\mathrm{pH}$ of Meat Proximate composition of rabbit meat was determined following the procedures of A.O.A.C (2000). Moisture was determined by drying $2 \mathrm{~g}$ of meat in an oven at $105^{\circ} \mathrm{C}$ until a constant weight was obtained. Crude protein was determined by using kjedahl method which comprised digestion distillation and titration of the distillate. Crude protein value was obtained by converting nitrogen ( $\mathrm{N} \%$ ) content obtained with a constant (6.25), thus crude protein was obtained as $(6.25 \mathrm{x} \mathrm{N} \%)$. Fat content of the meat was determined with soxhlet extraction method using petroleum ether. $2 \mathrm{~g}$ of meat sample was dried in an oven and the fat extracted. Ash content of the meat was determined by igriting it in a muffle farnace at $600^{\circ} \mathrm{C}$ to a constant weight.

The $\mathrm{pH}$ of meat was carried out by homogenising $10 \mathrm{~g}$ of meat sample for 5 minutes with $90 \mathrm{ml}$ distilled water using a blender (plate $5 \mathrm{~mm}$ ) model 242, Nakai, Japan. The $\mathrm{pH}$ was measured with $\mathrm{pH}$ meter model H18424 micro-computer, Havana Instruments Romania (Marchiori and DeFelicio, 2003).

\section{Sensory Evaluation of Meat}

This was conducted using a 10 member semi-trained taste panel (AMSA, 1995). The taste panelists were provided with unsalted biscuts and water for use in between treatment meat samples. The meat samples were coded after broiling at $160^{\circ} \mathrm{C}$ in an oven for 25 minutes to an internal temperature of $70^{\circ} \mathrm{C}$ and cooled to room temperature $\left(25^{\circ} \mathrm{C}\right)$. The meat samples were presented sequentially to the taste panelists on clean saucers. Meat sample from each treatment was evaluated independently of the other on a 9-point hedonic scale where 1 $=$ dislike extremely and $9=$ like extremely for colour, flavour, tenderness, juiciness, texture and overall acceptability.

\section{Statistical Analysis}

Data generated were subjected to analysis of variance (ANOVA) using (SAS, 2002), while significant means were separated with Duncan multiple range test of the same software.

\section{Results and Discussion}

The mean physical characteristics of differently stunned rabbit carcasses are shown on Table 1. Stunning did not have significant $(\mathrm{P}>0.05)$ effect on live and bled weights of rabbits. The weight and percentage blood loss were higher $(\mathrm{P}<0.05)$ in rabbits stunned with gas followed by those of rabbits stunned mechanically, while they were least $(\mathrm{P}<0.05)$ in rabbits stunned electrically. Dressed weight, dressing percentage, chilled carcass weight and chilling loss were higher $(\mathrm{P}<0.05)$ in rabbits carcasses stunned electrically, followed by those of rabbits carcasses that were not stunned (control) and least $(\mathrm{P}<0.05)$ in the carcasses of rabbit that were stunned with gas. These results could be due to low blood loss from the carcasses of electrically stunned rabbits.

The results showed that gas stunning encouraged high blood drain from the rabbit carcasses, hence lower dressed weight and dressing percentage. In the same vein, lower percentage chilling loss was observed in rabbit carcasses stunned with gas probably much fluid would have been lost with blood during bleeding. In contrast low blood loss was observed in rabbit carcasses stunned electrically which could have encouraged higher dressed weight, 
Apata, Eniolorunda, Amao, Okubanjo

Table 1: Carcass Characteristics of differently Stunned Rabbits

\begin{tabular}{lllll}
\hline & \multicolumn{4}{c}{ Treatments } \\
Variable & \multicolumn{1}{c}{1} & \multicolumn{1}{c}{2} & \multicolumn{1}{c}{3} & 4 \\
\hline Live weight (g) & $1350.00 \pm 0.06$ & $1370.00 \pm 0.03$ & $1360.00 \pm 0.03$ & $1380.00 \pm 0.02$ \\
Bled weight (g) & $1310.00 \pm 0.05$ & $1350.00 \pm 0.02$ & $1280.00 \pm 0.05$ & $1330.00 \pm 0.03$ \\
Blood loss (g) & $40.00 \pm 0.75^{\mathrm{c}}$ & $20.00 \pm 1.07^{\mathrm{d}}$ & $80.00 \pm 0.32^{\mathrm{a}}$ & $50.00 \pm 0.56^{\mathrm{b}}$ \\
Blood loss (\%) & $2.56 \pm 0.20^{\mathrm{c}}$ & $1.46 \pm 0.26^{\mathrm{d}}$ & $5.88 \pm 0.08^{\mathrm{a}}$ & $3.62 \pm 0.10^{\mathrm{b}}$ \\
Dressed weight (g) & $690.00 \pm 2.59^{\mathrm{b}}$ & $790.00 \pm 1.73^{\mathrm{a}}$ & $580.00 \pm 2.83^{\mathrm{d}}$ & $620.00 \pm 1.97^{\mathrm{c}}$ \\
Dressing (\%) & $51.11 \pm 0.06^{\mathrm{b}}$ & $57.66 \pm 0.04^{\mathrm{a}}$ & $42.65 \pm 0.15^{\mathrm{d}}$ & $48.55 \pm 0.14^{\mathrm{c}}$ \\
Chilled carcass weight (g) & $675.00 \pm 0.12^{\mathrm{b}}$ & $760.00 \pm 0.11^{\mathrm{a}}$ & $578.00 \pm 0.18^{\mathrm{c}}$ & $660.00 \pm 0.13^{\mathrm{b}}$ \\
Chilling loss (\%) & $2.17 \pm 1.08^{\mathrm{b}}$ & $3.80 \pm 0.61^{\mathrm{a}}$ & $0.35 \pm 1.87^{\mathrm{d}}$ & $1.49 \pm 1.26^{\mathrm{c}}$ \\
\hline
\end{tabular}

abcd: Means on the same row with different superscripts are statistically significant $(\mathrm{P}<0.05)$

dressing percentage, as well as high percentage chilling loss probably due to the fact that more fluid and blood were retained in the carcasses which might have added to their weights.

Visual colour score was higher $(\mathrm{P}<0.05)$ in rabbit meat stunned with gas (Table 2), followed by those of rabbits stunned mechanically and least $(\mathrm{P}<0.05)$ in rabbit meat stunned electrically. Since blood loss was higher in rabbit stunned with gas, less blood could have been retained in the muscles and there could be little or no blood stain of the meat hence its high visual appeal as against the meat of rabbits that were stunned electrically with high blood stained muscles. This result was in line with the report of Maria et al. (2000). Cooking loss, thermal shortening and drip loss were lower $(\mathrm{P}<0.05)$ in meat from rabbits stunned with gas, while they were higher $(\mathrm{P}<0.05)$ in meat from rabbits stunned electrically. Cooking yield values were higher $(\mathrm{P}<0.05)$ in meat from rabbits stunned with gas and lower $(\mathrm{P}<0.05)$ in meat from rabbits stunned electrically. The shear force values were higher $(\mathrm{P}<0.05)$ in meat from rabbits in control while they were lower $(\mathrm{P}<0.05)$ in meat from rabbits in treatment 2,3 , and 4 . These results could be due to the fact that WHC was high in prerigor muscle of rabbits stunned electrically because of high $\mathrm{pH}$ in the meat water could escape in form of drip and cooking losses. When $\mathrm{pH}$ is low, meat tends to lose its water content, this was not observed in meat from rabbits stunned with gas as the meat was able to retain its water contents

Table 1: Carcass Characteristics of differently Stunned Rabbits

\begin{tabular}{lllll}
\hline \multicolumn{5}{c}{ Treatments } \\
Variable & \multicolumn{1}{c}{1} & \multicolumn{1}{c}{2} & \multicolumn{1}{c}{3} & \multicolumn{1}{c}{4} \\
\hline Live weight (g) & $1350.00 \pm 0.06$ & $1370.00 \pm 0.03$ & $1360.00 \pm 0.03$ & $1380.00 \pm 0.02$ \\
Bled weight (g) & $1310.00 \pm 0.05$ & $1350.00 \pm 0.02$ & $1280.00 \pm 0.05$ & $1330.00 \pm 0.03$ \\
Blood loss (g) & $40.00 \pm 0.75^{\mathrm{c}}$ & $20.00 \pm 1.07^{\mathrm{d}}$ & $80.00 \pm 0.32^{\mathrm{a}}$ & $50.00 \pm 0.56^{\mathrm{b}}$ \\
Blood loss (\%) & $2.56 \pm 0.20^{\mathrm{c}}$ & $1.46 \pm 0.26^{\mathrm{d}}$ & $5.88 \pm 0.08^{\mathrm{a}}$ & $3.62 \pm 0.10^{\mathrm{b}}$ \\
Dressed weight (g) & $690.00 \pm 2.59^{\mathrm{b}}$ & $790.00 \pm 1.73^{\mathrm{a}}$ & $580.00 \pm 2.83^{\mathrm{d}}$ & $620.00 \pm 1.97^{\mathrm{c}}$ \\
Dressing (\%) & $51.11 \pm 0.06^{\mathrm{b}}$ & $57.66 \pm 0.04^{\mathrm{a}}$ & $42.65 \pm 0.15^{\mathrm{d}}$ & $48.55 \pm 0.14^{\mathrm{c}}$ \\
Chilled carcass weight (g) & $675.00 \pm 0.12^{\mathrm{b}}$ & $760.00 \pm 0.11^{\mathrm{a}}$ & $578.00 \pm 0.18^{\mathrm{c}}$ & $660.00 \pm 0.13^{\mathrm{b}}$ \\
Chilling loss (\%) & $2.17 \pm 1.08^{\mathrm{b}}$ & $3.80 \pm 0.61^{\mathrm{a}}$ & $0.35 \pm 1.87^{\mathrm{d}}$ & $1.49 \pm 1.26^{\mathrm{c}}$ \\
\hline
\end{tabular}

abcd: Means on the same row with different superscripts are statistically significant $(\mathrm{P}<0.05)$ 
Table 3: Proximate Composition and pH of differently Stunned Rabbit Meat

\begin{tabular}{lllll}
\hline \multicolumn{5}{c}{ Treatments } \\
Variable & \multicolumn{1}{c}{1} & \multicolumn{1}{c}{2} & \multicolumn{1}{c}{3} & \multicolumn{1}{c}{4} \\
\hline Moisture (\%) & $65.13 \pm 0.05^{\mathrm{c}}$ & $70.43 \pm 0.02^{\mathrm{a}}$ & $60.80 \pm 0.09^{\mathrm{d}}$ & $67.48 \pm 0.05^{\mathrm{b}}$ \\
Crude Protein (\%) & $22.25 \pm 0.12^{\mathrm{b}}$ & $22.20 \pm 0.09^{\mathrm{b}}$ & $23.50 \pm 0.02^{\mathrm{a}}$ & $22.35 \pm 0.07^{\mathrm{b}}$ \\
Fat (\%) & $2.80 \pm 0.05$ & $2.63 \pm 0.07$ & $2.45 \pm 0.03$ & $2.65 \pm 0.03$ \\
Ash (\%) & $1.33 \pm 0.00$ & $1.30 \pm 0.02$ & $1.25 \pm 0.05$ & $1.23 \pm 0.03$ \\
Nitrogen Free Extract (\%) & $8.49 \pm 0.07^{\mathrm{c}}$ & $3.44 \pm 0.07^{\mathrm{c}}$ & $12.00 \pm 0.03^{\mathrm{a}}$ & $6.29 \pm 0.04^{\mathrm{b}}$ \\
pH & $5.85 \pm 0.05^{\mathrm{ab}}$ & $6.20 \pm 0.05^{\mathrm{a}}$ & $5.20 \pm 0.07^{\mathrm{b}}$ & $6.15 \pm 0.07^{\mathrm{b}}$ \\
\hline abcd: Means in the same row with different superscripts are statistically significant $(\mathrm{P}<0.05)$ &
\end{tabular}

from escaping due to the fact that less water was lost in form of drip and cooking loss which culminated in low shear force value. Table 3 shows the results of proximate composition and the $\mathrm{pH}$ of differently stunned rabbits. Treatments 1 and 2 gave higher $(\mathrm{P}<0.05)$ moisture content followed by treatment 4 while treatment 3 gave the least $(\mathrm{P}<0.05)$ moisture. The high moisture content observed in treatment 2 could have contributed to high cooking and drip losses observed in the meat from rabbits in this group. However, meat from rabbits stunned with gas had higher $(\mathrm{P}<0.05)$ protein and Nitrogen Free Extract (NFE) values as well as lower $(\mathrm{P}<0.05) \mathrm{pH}$. Moisture and protein contents of meat are inversely related (Aduku and Olukosi, 2000) since protein concentration increases as moisture content decreases. High NFE in meat of rabbits in group 3 could be due to the fact that the onset of glycolysis was delayed in the carcasses, but could have started earlier in carcasses in groups 1 and 2 thereby depleting the glycogen reserves quickly than in rabbits in group 3 whose carcasses might have attained lower $\mathrm{pH}$ within a shortest possible period of time pre-rigor as observed in this study. There were no significant $(\mathrm{P}>0.05)$ differences in the fat and ash contents of meat from rabbits across the treatments.

All palatability trait scores were higher $(\mathrm{P}<0.05)$ in meat from rabbits stunned with gas, compared with traits of meat from other treatments. High palatability attributes from meat of rabbit in treatment 3 could have been responsible for its high $(\mathrm{P}<0.05)$ overall acceptability. It had been reported (Boles and Pegg 1998; Dinh and Nhat, 2006) that colour of meat is the major attribute that gives the first impression that consumers have about meat and influences

Table 4: Sensory Scores of differently Stunned Rabbit Meat

\begin{tabular}{|c|c|c|c|c|}
\hline \multicolumn{5}{|c|}{ Treatments } \\
\hline Variable & 1 & 2 & 3 & 4 \\
\hline Colour & $3.50 \pm 0.04^{c}$ & $2.03 \pm 0.05^{\mathrm{d}}$ & $5.35 \pm 0.03^{\mathrm{a}}$ & $4.13 \pm 0.04^{b}$ \\
\hline Flavour & $4.18 \pm 0.05^{\mathrm{c}}$ & $3.13 \pm 0.08^{\mathrm{d}}$ & $6.83 \pm 0.01^{\mathrm{a}}$ & $5.20 \pm 0.03^{b}$ \\
\hline Tenderness & $3.23 \pm 0.06^{\mathrm{d}}$ & $5.30 \pm 0.03^{b}$ & $6.35 \pm 0.11^{\mathrm{a}}$ & $4.26 \pm 0.08^{\mathrm{c}}$ \\
\hline Juiciness & $3.30 \pm 0.07^{\mathrm{d}}$ & $4.20 \pm 0.05^{\mathrm{c}}$ & $6.53 \pm 0.08^{\mathrm{a}}$ & $5.3 \pm 0.06^{\mathrm{b}}$ \\
\hline Texture & $4.60 \pm 0.04^{\mathrm{c}}$ & $3.43 \pm 0.07^{\mathrm{d}}$ & $6.58 \pm 0.05^{\mathrm{a}}$ & $5.40 \pm 0.05^{\mathrm{b}}$ \\
\hline Overall acceptability & $4.65 \pm 0.05^{\mathrm{c}}$ & $3.50 \pm 0.10^{\mathrm{d}}$ & $6.70 \pm 0.04^{\mathrm{a}}$ & $5.52 \pm 0.06^{b}$ \\
\hline
\end{tabular}

abcd: Means in the same row with different superscripts are statistically significant $(\mathrm{P}<0.05)$ 
their selection of meat followed by flavour and texture of the meat. The results of sensory characteristics of rabbit meat obtained in treatment 3 could be attributed to low cooking drip losses, thermal shortening, shear force, moisture as well as high blood loss, WHC, $\mathrm{pH}$ and protein, due to favourable biochemical reactions in the rabbit carcasses stunned with gas.

\section{Conclusion}

Stunning is important in slaughtering operation prior to bleeding in order to immobilize animals as well as render them insensible to pain or stress, however, it can have profound effect on meat quality. Carcass and meat characteristics of differently stunned rabbits were comparatively better in rabbits stunned with gas (di-ethylether). Meat from animals stunned with gas was of high quality though it is under investigation due to animal welfare issue.

\section{References}

Aduku, A.O. and Olukosi, J.O. 1990. Rabbit Management in the Tropics. Living Book Series. G.U. Publication, Abuja, Nigeria. Pp 2-5.

Aduku, A.O. and Olukosi, J.O. 2000. Animal Products Processing and Handling in the Tropics. Living Books Series. GU Publication, Abuja, Nigeria. Pp 24-32.

AMSA 1991. Guidelines for meat evaluation. American Meat Science Association Committee on Guidelines for meat evaluation. Proceedings of $44^{\text {th }}$ Conf. of American Meat Science Assoc. the reciprocal meat conference vol. 44.

AMSA 1995. Research Guidelines for Cookery, Sensory Evaluation and Instrumental Measurement of Fresh
Meat. National Livestock and Meat Board. Chicago IL, U.S.A.

AOAC 2000. Official Methods of Analysis, $19^{\text {th }}$ Edition AOAC $\backslash$ Inc. Washington, DC. 1219.

Barbut, S. 2000. Problems of Pale, Soft, Exudative meat in broiler chickens. Br. Poult. Sci. 38: 355-368.

Boles, J.A. and Pegg, R. 1998. Meat colour: Montana State University and Saskatchewan Food Product Innovation Programme. University of Saskatchewan USA 10-4.

Dal Bosco, A; Castellini, C; Bernardini, M. 1997. Effect of Transportation and Stunning Method on Some Characteristics of rabbit carcasses and meat. World Rabbit Sci. 5:115 - 119.

Dallezotte, A. 2002. Perception of rabbit meat quality and major factors influencing the rabbit carcass and meat quality. Livestock Prod. Sci. 75: 11 32.

Dinh, T. and Nhat, T. 2006. Meat quality: Understanding of meat tenderness and influence of fat content on meat flavour. Sci and Tech. Devpt. 9(12): 65-70.

Facco-Silveria, E.T.N, Silviera, F.A. and Beraquet, N.J. 1998. The influence of stunning techniques on some quality aspects of pig meat. Proceedings of $44^{\text {th }}$ Inter. Congress of Meat Science and Technology Barcelona, Spain; 1072 1073.

Grandin, T. 1980a. Mechanical, Electrical and Anesth etic Stunning Methods for Livestock. Int. J. Study Anim. Probs. 1: $242-263$.

Grandin, T. 1980b. The effect of stress on livestock and meat quality prior to and during slaughter. Int. J. Study Anim. Probs. 1:313-337.

Honikel, J.L. 1998. Reference methods for the assessment of physical 
characteristics of meat. Meat Sci. 49: $441-457$.

Insausti, K; Beriain, M.J; Purroy, A; Alberti, P; Gorraiz, C; and Alzueta, M.J. 2001. Shelf-life of beef from local Spanish cattle breeds under modified atmosphere. Meat Sci. 57: $273-281$.

Manteca, X. (1998). Neurophysiology and assessment of welfare. Proc. $44^{\text {th }}$ Inter. Congress of Meat Science and Technology Barcelona, Spain; 146 153.

Marchiori, A.F. and DeFelicio, P.E. 2003. Quality of wild boar meat and commercial pork. Sci Agric. Piracicaba, Braz; 60(1): 1-10.

Maria, G; Lopez, R and Lafuente, M.L. 2000. Evaluation of electrical stunning method using alternative frequencies in commercial rabbits. Meat Sci. 57: $137-143$.

Mulder, R.W. 1999. Hygiene during transport, slaughter and processing. In: Poultry Meat Science (Ed) Richardson R. I, Mead, G.C.) CAB, Publishing. $227-284$.
Okuba n j o, A.O. 1997. Me a t Characteristics of Singed and Conventionally dressed chevon carcasses J. Food Sci. Technol. 34(6): 494-497.

Omojola, A.B. 2007. Effect of delayed bleeding on carcass and eating qualities of rabbit meat Pak. J. Nutri. 6(5): $438-442$.

Omojola, A.B. and Adesehinwa A.O.K. 2006. Meat Characteristics of Scalded, Singed and Conventionally dressed rabbit carcasses World J. Zool. 1(1): 24 -29 .

Sams, A.R. 1999. Commercial implementation of post-mortem electrical stimulation. poultry Sci. 78:290-294.

SAS 2002. Statistical Analysis System. Version 9 SAS Institute Inc. Garry, NC, U.S.A.

Sukuki, A; Kaina, N and Ikeuchi, Y. 1991. Carcass composition and meat quality of Chinese pure bred and European X Chinese Cross bred pigs. Meat Sci. 29: 31 - 41 .

Received: $14 / 08 / 12$ Accepted: 27/08/13 